\title{
A IDENTIDADE EXISTENCIAL FEMININA NO CONTO “A IMITAÇÃO DA ROSA” DE CLARICE LISPECTOR
}

\section{THE EXISTENTIAL FEMALE IDENTITY IN THE SHORT STORY "A IMITAÇÃO DA ROSA" DE CLARICE LISPECTOR}

\author{
Wilma Santos Coqueiro ${ }^{1}$ \\ Maiara Cristina Segato ${ }^{2}$
}

\begin{abstract}
Resumo: Clarice Lispector, precursora da literatura de autoria feminina no cenário brasileiro, em muitas de suas narrativas, em especial a coletânea de contos Laços de família, publicada em 1960, representa mulheres que protagonizam, no contexto familiar e no ambiente doméstico, uma crise entre a condição de submissão e inferioridade que lhes legam a tradição patriarcal e uma experiência de libertação provocada por súbitos momentos de epifania. Sendo assim, analisaremos o conto "A imitação da rosa", um dos treze contos presente em Laços de família, no qual, apresentando uma temática voltada para as questões existenciais e feministas, retrata o aprisionamento da personagem à condição feminina e o desejo de liberdade que a persegue. No conto, a mente dividida de Laura, personagem central, enfrenta um embate entre os anseios internos e as exigências do mundo externo. Os conflitos interiores, vividos pela personagem, confrontam-se com um ideal de formulação de identidade, levando-a a uma intensa crise existencial e ao desejo de transgressão aos valores impostos pela sociedade, a fim de se reencontrar como mulher.
\end{abstract}

Palavras-chave: Clarice Lispector; conflitos existenciais; identidade feminina.

\begin{abstract}
Clarice Lispector, precursory of de literature of female authorship in the Brazilian scenary, in many of her narratives, specially the anthology of short stories Laços de familia, published in 1960, which represents women who act out as protagonist, in the familiar context and in the domestic environment, a crisis between the submission condition and the inferiority which devise the patriarchal tradition and one experience of liberation incited by unexpected moments of epiphany. This way, the short story "A imitação da rosa" will be analised, it is one of the thirteen short stories present in Laços de familia, whose thematic is turned to existential and feminist issues and it shows the imprisonment of the character to the female condition and the desire os liberty which pursue her. In the short story, the divided mind of Laura, the main character, faces an opposition between the interior desire and the exigency of the external world. The interior conflicts, lived by the character, confront with an ideal of identity formulation, leading her to an intense existential crisis and to the desire of trespass to the values imposed by the society, in order to meet herself as a woman.
\end{abstract}

Keywords: Clarice Lispector; existential conflicts; female identity.

\footnotetext{
${ }^{1}$ Professora assistente do Departamento de Letras da Universidade Estadual do Paraná - Campus de Campo Mourão - UNESPAR/FECILCAM. E-mail: wilmacoqueiro@ibest.com.br

2 Graduanda do curso de Letras da Universidade Estadual do Paraná - Campus de Campo Mourão UNESPAR/FECILCAM. Integrante do grupo de pesquisa ELIT. E-mail: maiarasegatoletras@gmail.com
} 
Conforme Antônio Cândido (1977, p. 131), Clarice Lispector "soube criar o estilo conveniente para o que tinha a dizer. Soube transformar em valores as palavras nas quais muitos não veem mais do que sons ou sinais", tornando-a, assim, um dos valores mais sólidos e originais da nossa literatura. Desde sua estréia com a publicação inovadora Perto do coração selvagem, em 1944, Clarice Lispector é sem duvida um dos maiores nomes da literatura brasileira, ao lado de Machado de Assis e Guimarães Rosa, aparecendo, de forma representativa, na literatura de autoria feminina.

A linguagem é um aspecto central nas narrativas clariceanas, pois revela a relação entre o sujeito e a realidade. Segundo Nunes (1989, p. 145), trata-se de "uma escritura conflitiva, autodilacerada, que problematiza, ao fazer-se e ao compreender-se, as relações entre linguagem e realidade". Contudo, é uma linguagem fragmentária, pois nem sempre dá conta de fazer essa ponte entre o sujeito e a realidade. Às vezes, ela se torna falha, insuficiente e imperfeita na representação do mundo interior. É marca da autora a sutileza do humor, da ironia, uso diferenciado dos tempos verbais, utilização do discurso indireto livre, a fim de desencadear monólogos interiores com o objetivo de provocar, na personagem, o fluxo de consciência, bem como a utilização de figuras de linguagem como a metáfora insólita, "que valem como sintomas de crise da ficção introspectiva" (BOSI, 1989, p. 474), isto é, uma tensão psicológica que reflete na tensão linguística, pois "o envolvimento do personagem com a linguagem expressa um ritual presente" nas narrativas clariceanas (SANT'ANNA, 1973, p. 196).

Muitas têm sido as bases teóricas para as análises dos contos, crônicas e romances de Clarice Lispector, como, entre outras, a filosofia, a psicologia e as teorias feministas. No entanto, a análise de suas obras tem se centrado em três aspectos principais: a dimensão filosóficaexistencial; a escritura em si; e a questão do feminino. Essas perspectivas de análise, geralmente, são enfocadas individualmente. Todavia, abordaremos, neste trabalho, uma visão geral da ficção lispectoriana, já que a linguagem está vinculada às questões filosóficas e psicológicas vividas pelas personagens femininas, conforme afirma Barbosa (2001, p. 147): "Lispector examina a linguagem, dilemas existenciais, divisão de classes, problemas raciais e conflitos entre os sexos como intersecções de um mesmo discurso social”. Nesse sentido, a escritora trata da problemática humano-existencial atrelada à sociocultural, de modo que os momentos epifânicos denunciam a problemática existencial das personagens e, portanto, conduzem à revelação dos aspectos sociais. A posição ocupada pela mulher na ordem social, cultural e literária, a identidade feminina, as relações familiares, as relações de gênero entre homem e mulher, a relação do sujeito com a sua vida interior e exterior e o próprio fazer literário estão entre os principais temas de Clarice Lispector. 
Apesar de Clarice Lispector recusar o rótulo de feminista e negar influências de outros escritores, Rosembaum (2006, p. 37) afirma que podemos reconhecer "no 'realismo psicológico' chocante de James Joyce e na 'sondagem introspectiva' de Virgínia Woolf as principais afinidades de Clarice Lispector”. Já Benedito Nunes, crítico que mais se aprofundou na dimensão filosóficoexistencialista de Clarice, ao analisar as obras da escritora, encontrou suporte teórico nas teorias filosóficas de, entre outros, Heidegger, Jean-Paul Sartre e Kierkegaard e apontou na ficção clariceana uma temática marcadamente existencial. De acordo com o crítico:

O desenvolvimento de certos temas importantes da ficção de Clarice Lispector insere-se no contexto da filosofia da existência, formado por aquelas doutrinas que, muito embora diferindo nas suas conclusões, partem da mesma intuição Kierkegaardiana do caráter pré-reflexivo, individual e dramático da "existência humana", tratando de problemas como a angústia, o nada, o fracasso, a linguagem, a comunicação, das consciências, alguns dos quais a filosofia tradicional ignorou ou deixou em segundo plano. (NUNES apud SANT'ANNA, 1973, p. 182)

Para Lucia Helena (1997, p.27) é impossível "não ler o tema da emergência do feminino em Lispector". Segundo a autora, Clarice Lispector toma "a figuração do feminino como mote insistente para investigar não só a singular emergência da mulher na sociedade, marcada por enorme repressão, mas principalmente para recolocar a questão da mulher e a da inscrição do sujeito na história" (HELENA, 1997, p. 27). As mulheres que Clarice Lispector representa, ou seja, que habitam suas obras, "são incapazes de gerar sua própria autonomia" (HELENA, 1997, p. 45), reféns do cotidiano, retidas às dimensões de uma casa e confinadas aos limites do lar e da família, numa espécie de prisão emocional. Essas personagens, divididas entre deveres e desejos, vivem sempre em conflito, diretamente ligados à sua identidade, em um estado de inacabamento, em processo de se completar, "como uma espécie de essência da mulher que está sempre em processo de tornar-se mulher" (DINIS, 2001, p. 71). No entanto, "o mistério estabelece-se em torno de situações insólitas extraídas do cotidiano" (JOSEF apud RAMALHO, 1999, p. 173). Assim, mesmo sem querer e sem entender, essas personagens, inesperadamente, se deparam com o mistério, com o imprevisto, buscando em elementos exteriores e naturais, o seu interior, a sua identidade, a fim de fugir dessa existência moldada pelas convenções sociais. Contudo, por mais que essas personagens se defrontem com uma situação inesperada, de revelação interior, de ruptura em suas vidas, elas não terão um final feliz. Elas não conseguem encontrar uma "senda de plenitude, de encontro com sua própria identidade, ou de libertação" (HELENA, 1997, p. 45). Essas mulheres, através do momento epifânico, expõem seus desejos reprimidos, mas "não completam o seu processo de despertar para a autoconsciência, nem se libertam das garras que as aprisionam" (HELENA, 1997, p. 45). Segundo Lúcia Helena (1997, p. 
43) "há um encontro, um confronto e um desencontro sem final feliz", pois tudo termina de forma instável ou ameaçada, levando à loucura ou ao confinamento do lar novamente.

Nessa conjuntura, uma leitura pelo viés feminista e filosófico parece ser o eixo apropriado para a análise dos conflitos interiores vividos pelas personagens femininas, resultantes de suas condições e papéis socialmente impostos. Portanto, analisaremos o conto "A imitação da rosa", presente na coletânea Laços de família, publicada em 1960, do qual a escritora questiona, com muita ironia, o modelo familiar imposto pela tradição patriarcal, na qual a mulher, condenada à imanência, fica reduzida ao espaço privado e à vida doméstica, impedindo-a de atingir sua plenitude existencial.

Em "A imitação da rosa", a narrativa se realiza através de uma falsa $3^{a}$ pessoa que é um simulacro da primeira. Em certos momentos ocorre em $1^{\underline{a}}$ pessoa e em outros ocorre em $3^{\underline{a}}$ pessoa. No entanto, é importante salientar que, tanto em $1^{\underline{a}}$ quanto em $3^{a}$, o narrador é a própria personagem, ou seja, é Laura, a protagonista, quem relata. Há uma relação de aproximação e recuo que o narrador estabelece com a personagem por meio de um processo que Franco Junior (apud RAPUCCI; CARLOS, 2011, p. 98) denomina "focalização", isto é, "uma articulação entre uma perspectiva que narra "de dentro"', assumida pelo narrador em $1^{\text {a }}$ pessoa ou narrador personagem, "e uma perspectiva que narra "de fora"”, assumida pelo narrador em $3^{a}$ pessoa. No conto, quando o narrador está na posição de $1^{\underline{a}}$ pessoa é o momento em que a personagem se questiona, expõe os seus dramas, seus conflitos e seus anseios, mas, em certos momentos, esse narrador rompe a adesão com a personagem, sem deixar de sê-la, passando para a posição de $3^{\text {a }}$ pessoa, para, "de fora", à distância avaliar criticamente a personagem.

No cenário do conto, não ocorre ações efetivas, mas sim situações que compõem o universo íntimo da personagem, colaborando para as suas rememorações e reflexões. Os fatos acontecem no interior da mente da personagem e são divididos em três tempos que consistem no passado, presente e futuro. O passado é dividido em dois tempos, isto é, o tempo da obediência, da aceitação e da submissão e o tempo da ruptura, quando emerge suas inquietações e ela fica "doente", tendo de ser internada. No decorrer da narrativa, esse tempo é indicado por várias metáforas. O presente é o tempo em que ela retorna para a casa, após o internamento, e rememora os dois passados, havendo uma tensão entre esses dois tempos. E o futuro previsível é o tempo em que ela quer resgatar o passado da obediência, na tentativa de repetir esse tempo. No entanto, ela não consegue controlar o novo evento epifânico. A análise do conto fundamentase, principalmente, no tempo presente, em que a personagem, confrontando os seus dois passados, mergulha em crise existencial, ocasionando a epifania.

Deixamos claro que, segundo Dinis (2001, p. 95), em Clarice Lispector, o tempo "rompe com o domínio de Cronos", ou seja, "escapa do ciclo cronológico demarcado pelo relógio". Pois o 
tempo cronológico não consegue medir o tempo do evento demasiadamente intenso que desestabiliza a personagem. O narrador narra uma experiência que passou, mas, por meio dos tempos verbais escolhidos, nos dá a impressão de presentificação do evento narrado, isto é, faz com que o ato narrado volte à tona com toda a força de um "agora". Os dois passados, presente e futuro são importantes para a construção da narrativa, pois relatando o que viveu em um ontem no agora é que o narrador personagem busca compreender a dimensão do acontecimento que viveu e que ainda o atravessa. Contudo, o fator mais importante é que a personagem não vive encadeamentos de fatos, mas sim acontecimentos permeados por fluxos que a atravessa, fazendo com que cada instante seja absolutamente único no tempo, ou seja, o "instante-já", misturando o passado, presente e futuro (DINIS, 2001, p. 84-107).

A narrativa gira em torno de Laura, dentro do espaço fechado da casa e do cotidiano doméstico. No conto, a personagem Laura, esposa de Armando, está de volta ao lar, após período de internamento numa clínica psiquiátrica, esperando pelo marido para saírem com o casal de amigos Carlota e João. A narrativa dá certas evidências de que Laura tivera "problemas psicológicos" e estivera por determinado tempo ausente do convívio social, o que, na verdade, trata-se de inquietações da personagem em relação à sua existência moldada por convenções. Contudo, na sociedade em que ela estava inserida, sair do padrão era considerado uma doença, pois o que Laura tivera significava um desvio, uma rebeldia.

Ao chegar em casa, Laura deveria manter uma postura de "estar bem", mas ela ainda se encontrava em um estado psicológico de desorganização, pois continuava descontente e insatisfeita. As aspas de "estar bem", ironicamente, mostram que Laura precisa ter um comportamento "normal", prescrito socialmente, diante das pessoas à sua volta. A personagem não possuía uma identidade própria, pois esta era condicionada à superficialidade de uma vida metódica e artificial, escondida sob a máscara de esposa modelo, submissa e obediente: "Antes que Armando voltasse do trabalho a casa deveria estar arrumada e ela própria já no vestido marrom para que pudesse atender o marido enquanto ele se vestia, e então sairiam com calma, de braço dado como antigamente" (LISPECTOR, 2009, p. 34).

Segundo Hall (2000, p. 112), "as identidades são as posições que o sujeito é obrigado a assumir, 'sabendo', sempre, que elas são representações”. Assim, na tentativa de escapar de seus conflitos interiores, Laura se refugia na rotina e se esforça em inserir-se em um determinado perfil feminino. E o que justamente a desestabiliza é a consciência de estar desempenhando um papel contrário ao que gostaria, de ter que esquecer que tudo é encenação e acreditar na ilusão de que aquele papel era realmente seu. Laura tenta construir uma identidade, conforme Hall (2000, p. 107), "fundada na fantasia, na projeção e na idealização". No caso da personagem, os conflitos da identidade existencial vão muito além das questões como "quem nós somos" ou "de 
onde viemos". Esses se estendem para questões como "quem nós podemos nos tornar", "como nós temos sido representados" e "como essa representação afeta a forma como nós podemos representar a nós próprios" (HALL, 2000, p.108-109).

Laura, enquanto se arruma, relembra e imagina como seria o jantar com os amigos. marido conversaria coisas que saem nos jornais com João e ela conversaria coisas de mulheres com Carlota. Deixando, assim, definidos os papeis predeterminados para o sujeito feminino e masculino, isto é, homens conversam sobre questões públicas e mulheres conversam sobre questões relativas ao lar. Dessa forma, o papel feminino e masculino, culturalmente, construído é tido como se fosse inerente a natureza feminina e masculina:

O corpo, portanto, é seu destino: menstruação, gravidez, parto, amamentação e educação dos filhos consistem nos primeiros sinais da natureza responsáveis pela inscrição da mulher, e não do homem, como o sexo obstinado ao silencio e ao emparedamento no espaço privado e na obscuridade. Nessa ordem de ideias, coube ao homem toda a mobilidade, o espaço público, o domínio da palavra, o poder e, consequentemente, o direito de dominação. (ZOLIN apud RAPUCCI; CARLOS; 2011, p. 222)

Podemos notar, ainda, a tensão entre os dois passados quando Laura recorda sobre sua relação com a amiga Carlota: "submissa à bondade autoritária e prática de Carlota, recebendo enfim de novo a desatenção e o vago desprezo da amiga, a sua rudeza natural [passado da obediência], e não mais aquele carinho perplexo e cheio de curiosidade [passado da ruptura]" (LISPECTOR, 2009, p. 34, grifos nossos). Então, fingiriam amizade como se nada tivesse ocorrido:

Como um gato que passou a noite fora e, como se nada tivesse acontecido, encontrasse sem uma palavra um pires de leite esperando. As pessoas felizmente ajudavam a fazê-la sentir que agora estava "bem" sem a fitarem, ajudavam-na ativamente a esquecer, fingindo elas próprias o esquecimento como se tivessem lido a mesma bula do mesmo vidro de remédio. (LISPECTOR, 2009, pp. 34-35)

Importante destacar que no decorrer do conto "como" significa que tudo não passa de uma representação, pois a personagem está em uma fase de adaptação pós-desequilíbrio, tentando se restabelecer em seu papel anterior. Nesse momento, Laura se questiona há quanto tempo o marido estava esquecido dela, mas, ao olhar-se no espelho, percebe que, cuidando somente da casa e do marido, havia se tornado esposa e se esquecido de ser mulher. Assim, ela também se questiona há quanto tempo ela havia se esquecido de si própria, pois, para pertencer ao padrão social vigente, é como se fosse necessário deixar de existir, matar a liberdade de ser, resultando em uma desestruturação existencial da identidade da personagem, representada, aqui, pelo "olhar-se no espelho": "Seu rosto tinha uma graça doméstica, os cabelos eram presos com 
grampos atrás das orelhas grandes e pálidas. Os olhos marrons, os cabelos marrons, a pele morena e suave, tudo dava a seu rosto já não muito moço um ar modesto de mulher" (LISPECTOR, 2009, p. 35), ou seja, sem destaque, apagada, sem voz, insignificante, quase inexistente. Conforme o modelo idealizado e imposto pela sociedade, isto é, ser a boa esposa e dona-de-casa exemplar, a vida de Laura se resumia em regras comportamentais cada vez mais rígidas: " $1^{\circ}$ ) calmamente vestir-se; $2^{\circ}$ ) esperar Armando já pronta; $3^{\circ}$ ) o terceiro o que era? Pois é. Era isso mesmo o que faria. E poria o vestido marrom com gola de renda creme. Com seu banho tomado" (LISPECTOR, 2009, p. 35).

O conto mostra também que Laura e Carlota eram mulheres diferentes, pois Laura havia lido a "Imitação de Cristo" e Carlota não:

Carlota ambiciosa e rindo com força: ela, Laura, um pouco lenta, e por assim dizer cuidando em se manter sempre lenta; Carlota não vendo perigo em nada. E ela cuidadosa. Quando the haviam dado para ler a "Imitação de Cristo", com um ardor de burra ela lera sem entender, mas que Deus a perdoasse, ela sentira que quem imitasse Cristo estaria perdido - perdido na luz, mas perigosamente perdido. Cristo era a pior tentação. E Carlota nem ao menos quisera ler, mentira para a freira dizendo que tinha lido. (LIPSECTOR, 2009, p. 35-36)

A "Imitação de Cristo", denominada assim pela personagem, ironicamente, era um manual rígido de um Colégio religioso tradicional, o Sacré Coeur, da barra da Tijuca, no Rio de Janeiro. A "Imitação de Cristo" representa as regras que deveriam ser seguidas para se tornar o modelo de mulher perfeita, submissa, que não erra e que está sempre à disposição do marido. Assim era Laura, enquanto Carlota, por não ter lido o guia religioso, não seguia as regras, era uma mulher independente e destemida. Carlota era o que Laura gostaria de ser. Observa-se, também, a inferioridade e a submissão não somente no contexto familiar, mas também frente às ideologias religiosas, o que significa que Laura tem um comportamento direcionado e influenciado pelo modelo social e pelos dogmas religiosos.

A personagem Laura se mantinha sempre ocupada com os afazeres do lar para não ter que pensar. Ela lutava para manter um equilíbrio e procurava viver uma vida prática, tranquila e previsível. Mas em seu inconsciente emergiam desejos, dos quais ela insistia em negá-los e em sufocá-los, por considerá-los um perigo à situação segura que imaginava viver. Então, quando seus pensamentos a perturbavam e seus sentimentos reprimidos a tentavam, Laura se culpabilizava, visto que são considerados pecados pelos valores morais e religiosos da sociedade a qual pertencia. $O$ ato de pensar na cosmovisão de Clarice Lispector não se trata apenas de um ato voluntário ou racional, mas sim um acontecimento que arrebata as personagens, ou seja, se pensar é um ato incontrolável, exige certa prudência do ser pensante, porque pensar leva o ser ao risco do encontro com o caos, com um estado de experimentação e libertação, que o arrasta para 
longe dos territórios conhecidos e previsíveis. Portanto, no universo clariceano, o exercício do pensamento torna-se um ato de transgressão, pois nasce da experimentação das sensações, produzindo, assim, "um pensar-sentir" (DINIS, 2001, p. 127), isto é, uma forma inusitada de libertar o corpo de suas amarras e de experimentar o mundo de diferentes formas. Laura ia até a cozinha e tomava um copo de leite, como se estivesse tomando uma dose de inocência, indenizando a todos e se penitenciando:

Se o médico dissera: "Tome leite entre as refeições, nunca fique com o estômago vazio, pois isso dá ansiedade" — então, mesmo sem ameaça de ansiedade, ela tomava sem discutir gole por gole, dia após dia, não falhara nunca, obedecendo de olhos fechados, com um ligeiro ardor para que não pudesse enxergar em si a menor incredulidade [...] aquele copo de leite que terminara por ganhar um secreto poder, que tinha dentro de cada gole quase o gosto de uma palavra e renovava a forte palmada nas costas, aquele copo de leite ela o levava à sala, onde se sentava "com muita naturalidade", fingindo falta de interesse, "não se esforçando" - e assim cumprindo espertamente a segunda ordem. "Não tem importância que eu engorde", pensou, o principal nunca fora a beleza. (LISPECTOR, 2009, p. 36-37)

Laura, já arrumada, sentada no sofá da sala, olha ao redor e vê em sua casa uma intranquilidade e impessoalidade, porém perfeita. Nesse momento, tempo presente, Laura confronta os seus dois passados, o da obediência e o da ruptura, provocando um ir e vir do consciente para o inconsciente com recordações progressivas, das quais envolvem sua relação com o marido, como se estivesse colocando-a em uma balança. Laura se lembra dos momentos de cansaço e descontentamento que o passado da obediência lhe impunha e dos momentos de liberdade e satisfação interior que o passado da ruptura, ocasionado pela "doença", Ihe proporcionara. Dessa forma, a personagem sente-se em dúvida entre assumir sua vontade de vivenciar outras realidades e seu desejo de viver com plenitude ou continuar seguindo a mesma vida convencionada:

Se uma pessoa perfeita do planeta Marte descesse e soubesse que as pessoas da Terra se cansavam e envelheciam, teria pena e espanto. Sem entender jamais o que havia de bom em ser gente, em sentir-se cansada, em diariamente falir; só os iniciados compreenderiam essa nuance de vício e esse refinamento de vida. E ela retornara enfim da perfeição do planeta Marte. Ela, que nunca ambicionara senão ser a mulher de um homem, reencontrava grata sua parte diariamente falível. De olhos fechados suspirou reconhecida. Há quanto tempo não se cansava? Mas agora sentia-se todos os dias quase exausta e passara, por exemplo, as camisas de Armando, sempre gostara de passar a ferro e, sem modéstia, era uma passadeira de mão cheia. $\mathrm{E}$ depois ficava exausta como uma recompensa. Não mais aquela falta alerta de fadiga. Não mais aquele ponto vazio e acordado e horrivelmente maravilhoso dentro de si. Não mais aquela terrível independência. Não mais a facilidade monstruosa e simples de não 
dormir - nem de dia nem de noite - que na sua discrição a fizera subitamente super-humana em relação a um marido cansado e perplexo. (LISPECTOR, 2009, p. 37-38)

Clarice Lispector, em suas obras, faz mais que uma divisão entre homens e mulheres, ela faz que o mundo masculino seja ameaçado pela força do instante epifânico feminino, pois, por meio dele, a mulher tenta superar a sua suposta inferioridade, invertendo-se, assim, a tradicional relação masculino versus feminino. Nesse jogo dialético de rememorações dos dois passados de Laura, podemos perceber como era a sua relação com o marido antes e depois do momento de ruptura. Se no tempo da obediência o marido "era esquecido de sua mulher", "em paz" e "recostado com abandono" (LISPECTOR, 2009, p. 34-35), após o momento de ruptura ele se tornara "cansado e perplexo", "mudo de preocupação", com o "hálito infeliz", "sorriso fixo" e "esforçando-se no seu heroísmo por compreender" a mulher (LISPECTOR, 2009, p. 38). E Laura, que antes era o perfeito modelo de esposa do "Sacré Coeur", sempre à disposição do marido, "arrumada e limpa" (LISPECTOR, 2009, p. 35), após o momento de ruptura, passou a sentir uma "piedade pungente" e, "como um barco tranquilo se empluma nas águas, se tornara superhumana" (LISPECTOR, 2009, p. 38).

No entanto, Laura retorna ao lar, ao que considera a normalidade, e decide por se libertar do desejo de viver, porque, provavelmente, ela considerava mais "prudente" a segurança da vida doméstica. Então, ela se ilude com a realidade que lhe é imposta e repete o tempo todo o que deve fazer, como se fosse para a sua aceitação, como se ela tivesse de se impor àquela condição. O discurso da personagem busca o convencimento do leitor de que tudo é perfeito, mesmo que, no fundo, nem ela acredite nisso. Como forma de satisfação, ela recusa-se a ser o que realmente é para agradar o esposo Armando e aos valores daquela sociedade e faz um extremo esforço de se convencer de que está bem: "Passara a ferro as camisas de Armando, fizera listas metódicas para o dia seguinte, calculara minuciosamente o que gastara de manhã na feira, não parara na verdade um instante sequer. Oh como era bom estar de novo cansada" (LISPECTOR, 2009, p. 37). Em suspiro de meia satisfação, para Laura, o cansaço é como uma espécie de missão cumprida ou uma espécie de prêmio. Essa e outras passagens do conto definem o perfil feminino tradicional, circunscrito somente em atividades domésticas.

Enquanto estava na sala, a espera de Armando, Laura cochila levemente, mas ao abrir os olhos "é como se fosse a sala que tivesse tirado um cochilo e não ela, a sala parecia renovada e repousada" (LISPECTOR, 2009, p. 42) e, então, ela percebeu um jarro de flores em cima da mesa:

Olhou-as com atenção. Mas a atenção não podia se manter muito tempo como simples atenção, transformava-se logo em suave prazer, e ela não conseguia mais analisar as rosas, era obrigada a interromper-se com a 
mesma exclamação de curiosidade submissa: como são lindas! [...] Mas sem saber por quê, estava um pouco constrangida, um pouco perturbada. Oh, nada demais, apenas acontecia que a beleza extrema incomodava. (LISPECTOR, 2009, p. 43)

As rosas a incomodam e a perturbam, pois significam a perfeição, mas, ao mesmo tempo, a desorganização da natureza, sem moldes e sem regras. As rosas exercem nela um contínuo e gradativo processo de sedução que vão do "olhar" ao "ver": "Olhou-o" [o vaso]; "Olhou-as"; "Olhouas à distância"; "E quando olhou-as, viu as rosas" (LISPECTOR, 2009, p. 42-46, grifo nosso). Provavelmente, a perfeição das rosas tenha provocado em Laura o impulso de romper novamente com seu lado submisso e subserviente, para se tornar "incansável", "super-humana", "independente", "tranquila", "perfeita" e "serena". A beleza das rosas fez com que Laura voltasse ao estado de transe que fizera com que ela fosse internada, anteriormente.

A imagem das rosas provoca o que muitos estudiosos, como, entre outros, Benedito Nunes (1973) e Affonso Romano de Sant'Anna (1973) denominam epifania, ou seja, "um momento de uma revelação súbita em que a "verdade" é desvelada para trazer os objetos à consciência" (JOSEF apud RAMALHO, 1999, p. 173). Mas que verdade é esta? É uma espécie de descortinamento interior que abre a consciência e leva o sujeito à reflexão, fazendo-o dar-se conta de sua problemática. Ou podemos dizer também que é um fulminante insight que permite, de certa forma, a reordenação do ser-no-mundo:

É um instante existencial, em quem as personagens clariceanas jogam seus destinos, evidenciando-se por uma súbita revelação interior que dura um segundo fugaz como a iluminação instantânea de um farol nas trevas e que, por isso mesmo, recusa-se ser apreendida pela palavra. Esse momento privilegiado não precisa ser excepcional ou chocante; basta que seja revelador, definitivo, determinante. Atinge a escritora o anelo de todo ficcionista: o momento da lucidez plena, em que o ser descortina a realidade íntima das coisas e de si próprio. (SÁ, 1993, p. 165)

A teoria da epifania, percepção reveladora de uma dada realidade, torna-se fundamental para a leitura de toda a narrativa de Clarice Lispector. Esse evento, presente em praticamente todos os trabalhos da escritora, é recorrente do drama existencial das personagens, que querem escapar de uma vida mecanizada:

A curva que a maioria dos personagens traça é essa inclusão e exclusão da epifania, a lembrança de um certo momento atingido ou por atingir. $E$ assim a obra vai se formando de momentos epifânicos, transformando-se ela mesma na materialização da epifania. (SANT'ANNA, 1973, p. 209)

Benedito Nunes (1973, p. 79), afirma que esse episódio epifânico ou "tensão conflitiva" que funciona como núcleo da narrativa, é provocado por algo banal do cotidiano em um momento 
fugidio, o que resulta no clímax, estabelecendo uma "ruptura da personagem com o mundo", mediada por uma situação de confronto de pessoa a pessoa e de pessoa a coisa, seja esta um objeto ou um ser vivo, animal ou vegetal.

Os momentos epifânicos, de modo geral, são traumáticos e dolorosos, pois provêm de uma forma emocional violenta de angústia que revelam a fragilidade da condição humana, ocasionando questionamentos e rupturas de valores. A epifania provoca uma visão ilimitada das possibilidades da vida e uma afirmação da liberdade em meio ao absurdo da existência.

A angústia nos desnuda, reduzindo-nos àquilo que somos: consciências indigentes, com a maldição e o privilégio que a liberdade nos dá. No extremo de nossas possibilidades, ao qual esse sentimento nos transporta, ela intensifica a grandeza e a miséria do homem. Da liberdade que engrandece, e que nos torna responsáveis de um modo absoluto, deriva a razão de nossa miséria. Vivemos, afinal, num mundo puramente humano, onde a consciência é a única realidade transcendente. (NUNES, 1966, p, 17)

Sendo assim, a imagem das rosas the provoca sentimentos dormentes e desconhecidos, desencadeando um súbito processo de autoconhecimento e um intenso desejo de liberdade e de transgressão aos valores impostos pela sociedade. Por meio das rosas, ela desperta, mesmo contra a sua vontade, e as sensações inundam o seu mundo, levando-a a mergulhar em crise, questionando a sua existência. Laura sente os sentimentos fugirem ao seu controle, causando-lhe prazer, medo e culpa.

Quando Laura enxerga as rosas, apesar do fascínio, ela se sente extremamente culpada, como se tivesse pecado por tê-las comprado, mas tenta se convencer de que não era, pois "não fora de modo algum ela quem quisera comprar, o vendedor insistira muito e ela se tornava sempre tão tímida quando a constrangiam, não fora ela quem quisera comprar, ela não tinha culpa nenhuma" (LISPECTOR, 2009, p. 46-47). A culpa é o momento extremo da sensação de ruptura e de tensão entre o Eu e o Outro, entre o Eu e o cotidiano, entre o Eu e o mundo, decorrente do processo epifânico.

As rosas são metáforas da tentação humana e dos sentimentos reprimidos. Elas provocam um incômodo desejo de experimentar e de transgredir. Laura tinha "seus sentimentos secretos" como toda mulher. No entanto, ela tinha de sufocá-los, pois deveria satisfazer unicamente aos desejos do marido: "Armando encararia com benevolência os impulsos de sua pequena mulher, e de noite eles dormiriam juntos" (LISPECTOR, 2009, p. 45). Laura, assim como maioria das mulheres que viviam em sua sociedade, internalizara os valores e as normas a ponto de ela mesma se desvalorizar como mulher. É o que podemos notar nas reflexões de Laura, imbuídas de um discurso moralizante. 
Ela sentia-se culpada por ter comprado rosas tão bonitas, porque queria se enquadrar no socialmente aceito: "Era preciso nunca mais dar motivo para espanto, ainda mais com tudo ainda tão recente. E, sobretudo, poupar a todos o mínimo sofrimento da dúvida. E que não houvesse nunca mais necessidade da atenção dos outros [...] Nada de impulsos" (LISPECTOR, 2009, p. 45). Então, ela, após muito hesitar, decide dar as rosas à amiga Carlota, pois, afinal, as rosas parecem não ter nenhuma funcionalidade dentro do cotidiano doméstico a não ser a de enfeitar. $\mathrm{E}$ Laura não quer despertar a atenção dos outros com extravagâncias e vaidade.

[...] porque que não pedir a Maria para passar por Carlota e deixar-Ihe as rosas de presente? E também porque aquela beleza extrema incomodava. Incomodava? Era um risco. Oh, não, por que risco? apenas incomodava, eram uma advertência, oh não, porque advertência? (LISPECTOR, 2009, p. 43)

A sensação é de que se ela se livrasse das rosas, acabaria o problema. No entanto, após a decisão de abnegar-se das rosas, o conflito apenas se acalmou, mas "as rosas haviam deixado um lugar sem poeira e sem sono dentro dela" (LISPECTOR, 2009, p. 50), ou seja, claro e desperto, pois é nesse estágio de aparente desequilíbrio mental que Laura enxerga as coisas com mais nitidez.

[...] Uma ausência que entrava nela como uma claridade. E também ao redor da marca das rosas a poeira ia desaparecendo. O centro da fadiga se abria em círculo que se alargava [...]Seu cansaço ia gradativamente se clareando. Sem cansaço nenhum, aliás. Assim como o vaga-lume acende. Já que não estava mais cansada, ia então se levantar e se vestir. Estava na hora de começar. Mas, com os lábios secos, procurou um instante imitar por dentro de si as rosas. (LISPECTOR, 2009, p. 50)

Imitar a rosa seria o oposto de imitar a cristo, ou seja, diferente da postura alienante de esposa e dona-de-casa modelo e da regularidade da vida cotidiana. Portanto, imitar a rosa é trazer à tona os desejos, sentimento e sonhos, conflitando com a realidade humana convencional.

Laura não percebe o tempo passar, pois seu tempo é subjetivo, mas já era noite, então o marido armando chega: "O vulto escuro e precipitado entrou, a luz inundou violenta a sala. E na porta mesmo ele estacou com aquele ar ofegante e de súbito paralisado como se tivesse corrido léguas para não chegar tarde demais" (LISPECTOR, 2009, p. 51). Ao ver a esposa, ele percebe que algo estava errado com ela, pois já não era mais aquela mulher "chatinha, boa e diligente, e mulher sua" (LISPECTOR, 2009, p. 51). Armando olhou Laura com um tom inexpressivo e desconfiado, percebendo "com horror que a sala e a mulher estavam calmas e sem pressa" (LISPECTOR, 2009, p. 52). Laura, enfim, confirma a constatação de Armando: “- Não pude impedir, disse ela, e a derradeira piedade pelo homem estava na sua voz, o último pedido de 
perdão que já vinha misturado à altivez de uma solidão já quase perfeita. [...] Foi por causa das rosas, disse com modéstia" (LISPECTOR, 2009, p. 52).

Armando a olhava "envelhecido, cansado, curioso. Mas não tinha uma palavra sequer a dizer. Da porta aberta via sua mulher que estava sentada no sofá sem apoiar as costas, de novo alerta e tranquila, como num trem. Que já partira" (LISPECTOR, 2009, p. 53). O "sem apoiar as costas" é uma atitude que afirma a sua liberdade e independência em relação ao marido e às amarras sociais que a prendiam. Laura estava novamente "alerta e tranquila" (LISPECTOR, 2009, p. 53), ou seja, duas palavras contraditórias assim como a própria personagem, dividida entre razão e emoção, entre ser livre e ser aprisionada, entre ter uma personalidade própria e ter uma escondida sob uma máscara social imposta, simbolizando, assim, a dualidade do ser humano e o desejo de unificação.

Segundo Affonso Romano Sant'Anna (1973, p. 204), depois da revelação, a personagem fica "definitivamente perturbada ou regressa ao repouso inicial. Mas continuará para sempre 'ferido nos olhos'”, pois é impossível às personagens, ao deflagrarem a epifania, retornarem ao "equilíbrio" do quadro inicial. Nesse conto, a personagem retorna ao estado inicial, contudo, esse retorno é a um estado mental anteriormente experimentado, isto é, "a loucura", e não à segurança do lar. Não sabemos em qual grau, mas podemos perceber que, de alguma forma, Laura se desliga das convenções, pois embarca no "trem da insanidade", uma insanidade que pode ser entendida como transcendência de um mundo "real".

\section{Referências:}

BARBOSA, Maria José Somerlate. Clarice Lispector: des/fiando as teias da paixão. Coleção Memória das Letras. Porto Alegre: EDIPCRS, 2001.

BOSI, Alfredo. Clarice Lispector. In: História concisa da literatura brasileira. São Paulo: Cultrix, 1989.

CÂNDIDO, Antônio. No raiar de Clarice Lispector. In: . Vários escritos. São

Paulo: Duas Cidades, 1977.

DINIS, Nilson. A arte da fuga em Clarice Lispector. Londrina: Ed. UEL, 2001.

HALL, Stuart. "Quem precisa da identidade?" In: SILVA, Tomaz Tadeu da (Org.). Identidade e diferença: a perspectiva dos estudos culturais. $2^{2}$ ed. Petrópolis: Vozes, 2000.

HELENA, Lúcia. Nem musa, nem medusa: itinerários da escrita em Clarice Lispector. Niterói: EDUFF, 1997. 
FRANCO JUNIOR, Arnaldo. Linguagem, diferença e poder na obra inicial de Clarice Lispector. In: RAPUCCI, Cleide Antonia; CARLOS, Ana Maria (Orgs.). Cultura e representação: ensaios. Assis: Triunfal gráfica e editora, 2011.

JOSEF, Bella. Clarice Lispector e o ato de narrar. In: RAMALHO, Christina. Literatura e feminismo: propostas teóricas e reflexões críticas. Rio de janeiro: ELO, 1999.

LISPECTOR, Clarice. "A imitação da rosa". In: Laços de família. Rio de Janeiro: Rocco, 2009.

NUNES, Benedito. O Mundo de Clarice Lispector. Manaus: Edições Governo do Estado do Amazonas, 1966.

Leitura de Clarice Lispector. São Paulo: Quíron, 1973.

. 0 drama da linguagem: uma leitura de Clarice Lispector. São Paulo: Ática, 1989.

ROSEMBAUM, Yudith. Metamorfose do mal: uma leitura de Clarice Lispector. São Paulo: Editora da USP, FAPESP, 2006.

SÁ, Olga de. A escritura de Clarice Lispector. Petrópolis: Vozes, 1979.

SANT'ANNA, Affonso Romano de. Análise estrutural de romances brasileiros. 2. ed. Petrópolis: Vozes, 1973.

ZOLIN, Lúcia Ozana. Reflexões sobre a crítica literária feminista. In: RAPUCCI, Cleide Antonia; CARLOS, Ana Maria (Orgs.). Cultura e representação: ensaios. Assis: Triunfal gráfica e editora, 2011. 